\title{
Disruptive innovation and R\&D ownership structures
}

\begin{abstract}
This paper provides a theoretical explanation as to why breakthrough innovations seem to be possible only within capitalist economies (Kornai 2013). Specifically, our theory explains why disruptive innovations are discovered and financed by large numbers of independently owned small firms in capitalist economies rather than in socialist economies where state ownership is the only option. The key is that the ownership structure of the firm affects the ex-post selection of worthwhile discoveries, which determines the fate of disruptive innovation. Our paper also contributes to empirical work on disruptive innovation, which is missing in the literature. We use new molecular entities (NMEs) in the pharmaceutical industry as a proxy for disruptive innovation. Although pharmaceutical companies are often very large, their R\&D projects greatly depend on forming alliances with much smaller independent firms. We find that the number of NMEs discovered by pharmaceutical companies is positively and significantly associated with the number of $R \& D$ alliances in which they participate. Our theory is supported by the empirical findings.
\end{abstract}

Keywords: Disruptive innovation, ownership, soft budget constraint, capitalism, socialism

JEL Codes: G30, L2, O31, P51 


\section{Introduction}

In his most recent book, Dynamism, Rivalry, and the Surplus Economy, Janos Kornai (2013) investigates the fundamental differences between capitalism and socialism ${ }^{1}$ in innovativeness in general and Schumpeterian creative destruction in particular. By providing 87 examples of breakthrough, revolutionary innovations in the century beginning with the Soviet Union's birth, he finds that all of them were invented in capitalist economies. The Soviet socialist economy was not responsible for any. $\mathrm{He}$ concludes that not being able to foster revolutionary innovation distinguishes socialism from capitalism.

Why are socialist economies unable to generate revolutionary innovations while capitalist economies are able to do so? The present paper extends Kornai's discussion of innovation under different economic systems, focusing on the ownership of R\&D projects. We ask why disruptive innovations are mainly created in capitalist economies in general and by outsourced $R \& D$ alliances among large numbers of small, independent private startups in particular and why the internal R\&D departments of large corporations or R\&D branches of centralized socialist economies are unable to discover them. We also test the predictions of our theory empirically. The underlying logic of our theory is a generalized soft-budget constraint (SBC) (Kornai 1979, 1986, 2013; Dewatripond and Maskin 1995; Qian and Xu 1998). Since disruptive innovation is very uncertain (no one knows the statistical distribution of a project's promise ex-ante), ex-post screening is critical for solving the incentive problems associated with R\&D. Such ex-post screening relies on the hardness of the budget constraint faced, which reflects the commitment to the termination of failing projects. However, centralized institutions do not have that commitment capacity in ex-post R\&D project screening because they face SBCs. Relying on that logic, our theory explains why disruptive innovations are rarely invented in centralized institutions, such as large corporations in the market or centralized economies, and why they are mostly initially created in venture capital (VC)-financed startups and further developed by outsourced R\&D alliances involving multiple owners/financiers.

We test the predictions of our theory by investigating breakthrough innovations in the pharmaceutical industry. Measuring disruptive innovation is challenging because no well-recognized approach for doing so is available in the existing literature. We chose to focus on the pharmaceutical industry for two reasons. First, that industry is very R\&D intensive. In 2017 alone, biopharmaceutical companies in the United States invested approximately $\$ 97$ billion in R\&D (21.8\% of their total sales) (PhRMA 2018). Moreover, inventing revolutionary drugs is extraordinarily uncertain. Second, the pharmaceutical industry incorporates a systematic and objective measurement of R\&D outputs, i.e., the development of new molecular entities (NMEs) approved by the US Food and Drug Administration (FDA). NMEs are compounds that contain novel moieties, i.e., they are not derivatives of existing substances. They promise to provide critical new therapies for certain diseases. The FDA has established criteria

\footnotetext{
${ }^{1}$ We adopt Kornai's (1992) definition of socialism as an economy where state ownership dominates. Because the state is the sole owner and controls state firms, no clear boundary between the state and the firm exists in socialism. According to that definition, Western welfare states are not socialist.
} 
for measuring novel entities that are disruptive to existing drugs, and the standards are evidence-based and implemented rigorously. ${ }^{2}$ Because NMEs are more likely to lead to revolutionary treatments, we consider them an objective measure of disruptive innovation. In Section 4.1, we further discuss why NMEs serve as a more accurate measure of disruptive innovation than the alternatives adopted by the existing literature.

By examining NMEs invented by nations between 1998 and 2018, we find that, parallel to Kornai's (2013) conclusions about breakthrough innovations, all NMEs approved during the time were invented/discovered by firms in capitalist economies, and $56 \%$ of them were introduced by US firms. We also find that no company in the former or current socialist economies, including the Soviet Union and China, discovered any NME during the 1998-2018 period. ${ }^{3}$ Furthermore, forming R\&D alliances is critically important for pharmaceutical companies in developing NMEs. During the period studied, all pharmaceutical companies that succeeded in developing NMEs were active in outsourcing R\&D through industry alliances. Pharmaceutical companies with more R\&D alliances were more successful in developing NMEs. The number of $R \& D$ alliances formed by pharmaceutical companies is significantly and positively associated with obtaining approval of NMEs.

The paper addresses long-standing fundamental questions about why ownership matters and whether disruptive innovation is fostered better by socialism or capitalism. In doing so, it contributes to the literature on innovation, economic systems, and theories of the firm. Above all, the study contributes to the debate on the innovation and economic sustainability of different economic systems (Schumpeter 1950; Kornai 2013). We extend Kornai's discussion by identifying the mechanisms that explain why socialist economies or large firms in capitalist economies fail to generate breakthrough innovations. Borrowing from Maskin (1992) and Qian and Xu (1998), we provide a new contractual foundation for hardening budget constraints, and this foundation allows us to extend the SBC paradigm to a broad range of issues. Furthermore, the study contributes to the literature on the theory of the firm (Coase 1937; Williamson 1975; Hart 1995, 2017; Grossman and Hart 1986; Hart and Moore 1990). We ask what the boundary of the firm is in R\&D investment. Specifically, we explain why large firms in market economies tend not to integrate highly uncertain R\&D projects and fail to generate breakthrough innovations. Applying SBC theory, we identify the conditions under which large firms tend to integrate R\&D projects within their ownership boundaries and the conditions under which firms tend to finance such projects externally or jointly with other enterprises and give up ownership partly or completely, at least in early stages. Finally, the study complements the recent literature on innovation and market competition (Aghion et al. 2005; Acemoglu et al. 2006, 2018) and the literature on expert failure (Koppl 2018).

\footnotetext{
${ }^{2}$ We are aware of the problems of the bureaucracy and deficiencies of the FDA, which affect the quality of the drugs approved by them. For example, Klein and Tabarrok (2002) report inefficiencies and delays caused by the FDA. Lasser et al. (2002) document other deficiencies of the FDA. The inefficiency and inaccuracy of the FDA is equivalent to introducing type I and type II errors into our variable and lower the accuracy of NMEs as a proxy of disruptive innovation in drug R\&D. However, these problems do not substantially affect disruptive innovation of new drugs in the US (to be discussed in Section 4.1). We thank the editor and a referee for suggesting the related literature.

${ }^{3}$ Owing to their inability to invent NMEs, Russia and China rely heavily on the import of pharmaceuticals, and their domestically produced drugs typically are made from imported ingredients.
} 
We probe how the ownership structure or boundary of the firm plays a key role in generating disruptive innovation. Our theory also sheds light on syndicated financing (Esty and Megginson 2001). We emphasize the importance of the existence of multiple financiers with different specializations in R\&D financing to harden budget constraints and thus commit to timely termination of bad projects.

In the next section, we provide a brief overview of the relevant literature. In Section 3, we set up the model, which endogenizes the commitment problem in ownership integration and finds a solution for it in outsourcing. We report empirical evidence in Section 4. Finally, Section 5 presents concluding remarks.

\section{The literature}

Whether disruptive innovation is better fostered by socialism or capitalism is a fundamental, long-standing question. In the same book in which Schumpeter (1950) coined "creative destruction", he argued that only large firms, particularly monopolistic firms, are interested in innovation, and they see it as a means to reinforce their dominant positions (and that capitalism eventually will be replaced by socialism). Schumpeter's assignment of monopolistic firms as leaders in disruptive innovation runs parallel to notions of "market failure". According to that view, unable to capture the positive R\&D externalities of projects carried out by small enterprises, underinvestment in innovation will plague market economies (Hall and Lerner 2010). If one pushes the same argument further, one might even conclude that socialism should be more innovative than capitalism because no market failure will be observed in the former.

However, history shows that socialism is not good at disruptive innovation (Kornai 2013). Compared with capitalist economies, why are socialist economies unable to invent revolutionary products? In addressing that question, Kornai examines the characteristics of the innovation process in capitalist and socialist economies (Table 1). Factors (A), (C), (D) and (E) in Table 1 are related to competition and conflicts between winners and losers in that process, which are substantially different when they have hard budget constraints (HBCs) in capitalism and SBCs in socialism. An $\mathrm{HBC}$ is a critical factor in fostering disruptive innovations, and this factor is the foundation of the Schumpeterian creatively destructive process. As Kornai (2013, p. 34) notes, "[T]he Schumpeterian process of innovation ... has inevitably two sides: many projects are needed for the few great successes, and at the same time, we get too many of them". The upside is the creation of new products. The downside is that destruction implies the bankruptcy of old firms (HBC) and the "extinction" of old products. That disadvantage is an essential part of the Schumpeterian process and necessary for innovation and vibrant market mechanisms. However, only capitalism supports HBCs (Kornai et al. 2003), which provide conditions for investing in promising projects and rewarding successful entrepreneurs (Kornai 2013, p. 15). By contrast, in socialism with SBCs, loss-making firms are protected from going bankrupt, and innovation proceeds through a bureaucratic planning mechanism. Consequently, investment in R\&D is confined to a small number of politically favored 
projects, and the rewards for success are inadequate (Kornai 2013, p. 15).

[Table 1 about here]

Qian and Xu (1998) and Huang and Xu (1998) analyze innovation in capitalist and socialist economies, endogenizing points (A), (C), (D) and (E) in the two systems. The predictions of their models are consistent with the facts discussed in Kornai (2013). Creative destruction and HBCs are intimately related.

Similar to Schumpeter and Hayek, Kornai believes that the dynamic features of capitalism and socialism are among the most important subjects in economics. However, he is frustrated by what he perceives as a lack of understanding among economists and the general public about capitalism's potential to invent and innovate, which determine long-term growth, survival, and many other good or bad features of capitalism compared with socialism or any alternative system. The present paper studies the mechanism of the "highly visible great virtue of capitalism" theoretically and empirically.

Our theory is closely related to the theory of the firm. We ask what the boundary of the firm is in R\&D projects. Coase (1937) questioned the ownership structure of firms, from the smallest firms in the market economy to the largest firms in the socialist economy where all assets are state-owned (Lenin 1917). The present paper goes further along in the direction taken by Coase $(1937,1993)$. Coasean logic helps explain why it is not surprising that very large corporations in a market economy share some features of a centralized economy, such as the SBC problem in dealing with uncertain R\&D financing. According to Coasean analysis, transactions take place within the firm rather than in the market because doing so is less costly.

The more recent mainstream theory of the firm is based on the residual control rights emphasized by Hart (1995, 2017), sometimes referred to as the GrossmanHart-Moore theory (Grossman and Hart 1986; Hart and Moore 1990). Applying that theory, the decisions of large firms regarding internalizing or outsourcing $R \& D$ activities depend largely on the complementarities between R\&D projects and core business activities. If an R\&D project is strongly complementary to a large company's core business, the company should conduct the project in-house and have full ownership; it should be outsourced otherwise.

The literature mentioned above has considerably improved our understanding of the boundaries of the firm. However, those contributions hardly explain why capitalism is more capable of generating breakthrough innovations than socialism. In contrast to large firms in capitalist economies that are free to choose the optimal ownership structure for their R\&D projects, state-owned enterprises (SOEs) in socialist economies have no alternative ownership structure for the R\&D projects available to them. They can only conduct R\&D under state ownership, which is equivalent to internal financing in our theory. Nominally, many SOEs can be found in any socialist economy. However, all SOEs are controlled by the same government. Thus, from the control rights point of view (Hart 2017), SOEs are the operating divisions of one firm, the state. If we were to directly apply the control-rights theory of the firm (Grossman and Hart 1986; Hart and Moore 1990) to address questions 
about $\mathrm{R} \& \mathrm{D}$, we would arrive at the following answer: if $\mathrm{R} \& \mathrm{D}$ projects are complementary to the core business of the state-owned firm, carrying out all of them under full state ownership would be optimal. That is, under that condition, socialism would be more innovative than capitalism. However, that conclusion contradicts the empirical evidence.

Furthermore, some observations about capitalist economies may not be explained by the Grossman-Hart-Moore theory. In a capitalist economy, it is frequently observed that small firms consistently generate a disproportionate share of innovations (e.g., Scherer 1992), and the early stages of R\&D often take place in small firms, whereas later stages (the " $\mathrm{D}$ " in $\mathrm{R} \& \mathrm{D}$, that is, transforming basic research into commercially successful products and processes) require the resources of large firms (Kealey 1996). Large, mature corporations tend to restrict their internal R\&D activities to more certain and less new-product-related innovations (Scherer 1991, 1992). They often choose not to undertake highly uncertain R\&D projects within their ownership boundaries even if such projects are strongly complementary to their businesses but instead finance them with small independent firms by jointly engaging in R\&D alliances. As such, VCs and VC-financed startup firms have been responsible for launching most of the disruptive innovations over the past 60 years. Some innovative startup firms have grown rapidly and become industry-leading giants, such as Apple, Microsoft, Amazon, Google and Intel, whereas most small startups (such as DeepMind, Skype and Mobileye) were bought out by or merged with much larger companies. Relying on stories of disruptive innovations from the steam engine to today's information technology, Ridley (2020) argues that innovation is always a bottom-up, accidental process rather than an ordered, top-down process.

Another strand of the literature on innovation focuses on the dynamic relationship between R\&D investments and various economic factors. Huang and Xu (1999) study how finance in general, SBC finance in particular, affects economic growth through its impacts on innovation. Aghion et al. (2005) examine the relationship between competition and innovation intensity in different sectors. Acemoglu et al. (2006) explore the relationship between the development stage of an economy and innovation, arguing that for an economy on the technological frontier, the capability to select high-skilled entrepreneurs is the key to economic growth. Similarly, Acemoglu et al. (2018) study the dynamics of firms' entry and exit in the innovative process. However, no coherent theory has yet been advanced to explain the emergence of disruptive innovation.

In what follows, we attempt to fill the knowledge gaps in the existing literature. We extend Kornai's discussion of why capitalist economies are better able to generate breakthrough innovations than socialist economies using SBC theory. Moreover, we link the theory of the firm and SBC theory to identify the boundaries of the firm in R\&D activities. We try to identify the contributors to a large firm's decision about whether to maintain full ownership of an $R \& D$ project. More specifically, if $R \& D$ in disruptive technologies is vital to a large corporation, we ask, what is the optimal strategy and corresponding ownership structure of the firm? Should its major R\&D projects be conducted internally with full ownership (i.e., integration)? Alternatively, 
should they be outsourced with shared ownership (or even no ownership at all) by forming R\&D alliances with other stand-alone firms (i.e., non-integration)?

Thus, the primary question to be addressed by our theory is, if a large firm is not constrained by wealth in self-financing an R\&D project that is complementary to its core business, why should it ever choose to finance R\&D externally, as is overwhelmingly observed empirically? A concrete example is a leading pharmaceutical firm's efforts to develop new drugs through R\&D alliances instead of investing internally. A theory that addresses that question is, at the same time, an answer to its mirror question regarding $\mathrm{R} \& \mathrm{D}$ in a socialist economy.

The theory presented in our paper links the boundaries of the firm, or the ownership structure of $R \& D$ projects, with the features of such projects. We argue that the optimal determination of a firm's boundary in R\&D projects depends on the characteristics of $R \& D$ projects and the external financial environment. We suppose that the uncertainty associated with an R\&D project is so high that no one even knows its statistical distribution and that uncertainty can be reduced only after the project is carried out. Therefore, the ex-post selection of projects is crucial, whereas ex-ante selection can hardly be effective. However, an ex-post screening mechanism requires a commitment to stopping a bad project even when refinancing it is ex-post profitable (which means that the project's earlier sunk costs are ignored in an ex-post decision).

We show that outsourcing can be deployed as a commitment device for a large firm to terminate projects when they are revealed to be bad ex-post. With full ownership of an $R \& D$ project (integration), the firm may lose such commitment capacity. That is one cost of integration, and the more uncertain an $R \& D$ project is, the higher the cost it is to hold full ownership from the very beginning. Therefore, the ownership boundary of $R \& D$ projects is determined by the trade-off between the efficiency gain from solving the commitment problem-gaining the capacity to make sound ex-post selections - and the institutional cost of external financing. Here, the institutional cost of external financing refers to moral hazard and adverse selection problems, which have been discussed extensively in the literature (e.g., Adams et al. 2009; Hall and Lerner 2010; Steijvers et al. 2009). The trade-off implies that if a project is relatively certain, integration, i.e., internal $\mathrm{R} \& \mathrm{D}$, is more efficient; if a project is less certain, non-integration, i.e., outsourcing to $R \& D$ alliances, is more efficient.

Our theory also helps clarify syndicated financing. The syndicated loan market is one of the largest and fastest-growing sources of corporate financing. In 2000, banks extended \$2 trillion in syndicated loans. By way of comparison, bank-backed whole loans and leases in the United States in the same year totaled $\$ 3.88$ trillion; the total value of bank assets was approximately $\$ 6$ trillion (Esty and Megginson 2001). Our theory helps explain the paramount importance of such financial arrangements.

\section{The theoretical model}

We aim to specify an integrated theoretical model capturing the mechanisms of disruptive $R \& D$ in a private-ownership-dominated market economy. Additionally, the model will clarify $R \& D$ mechanisms in a state-ownership-dominated socialist 
economy. Without loss of generality, we consider a market economy characterized by numerous entrepreneurs and many large enterprises with dispersed ownership. We model socialism as an extreme reverse case in which only one large state-owned firm exists. Each entrepreneur in either economy generates one new idea for a single R\&D project with zero financing support. The large firm faces no wealth constraint for financing R\&D projects (that assumption reflects reality reasonably well because our model focuses solely on R\&D; relaxing the assumption somewhat will not change the model's qualitative results). In the market economy, when an entrepreneur proposes a project to a large firm and the firm is interested in the project, the firm can choose to either purchase the project, thus hiring the entrepreneur and financing it internally, or jointly form an R\&D alliance with other financiers, thus financing it externally. We assume the $R \& D$ alliance to be a non-integrated division of the firm that does not own the project exclusively. By contrast, an SOE in the socialist economy has no choice but to finance $R \& D$ internally because the state claims all ownership rights.

We presume that among all of the projects proposed by entrepreneurs, $\lambda$ percent of them are "good" and $1-\lambda$ percent of them are "bad". A good project takes two periods to finish and requires a total investment of $I_{1}+I_{2}$, where $I_{t}$ is the investment required in period $t=1,2$; moreover, $I_{1}$ and $I_{2}$ are sunk. A good project is profitable, and its market value is $\hat{V}>I_{1}+I_{2}$. A bad project produces no return after the second period, but it can be reorganized in the third period; such reorganization costs $I_{3}$. Thus, in total, a bad project takes three periods for completion and requires a total investment of $I_{1}+I_{2}+I_{3}$.

A good project will be completed at time 2 regardless of integration or non-integration within the ownership boundaries of the firm. Thus, from the perspective of financing decisions, no differences materialize among the different ownership cases. In the rest of the paper, we will focus on bad R\&D projects, which capture the high-failure-rate feature of disruptive innovation.

We suppose that the returns to a completed bad project under the best possible reorganization strategy adopted at time 3 can exceed the last period's investment; however, it is not efficient to continue the project after period 1. Therefore, in period 2, the financier(s) must decide whether to refinance it or liquidate it. It is noteworthy that we hereby assume that at $t=0$, all projects are worthy of being financed with a discount rate of zero.

We assume that the ex-ante distribution of the outcomes of all types of projects is public knowledge, but neither the large firm nor the entrepreneur precisely knows each project's type. At $\mathrm{t}=1$, after working on a project for one period, the entrepreneur discovers the project's type, but the large firm(s) does not have access to that knowledge. Henceforth, we assume that informational asymmetry exists between the entrepreneur and the large firm(s) in period 1. 
We suppose that an entrepreneur receives a private benefit, $b_{t}$, from working on a project, where $t=1,2,3$ denotes the date on which the project is either completed or terminated. ${ }^{4}$ Specifically, if the entrepreneur abandons the project at the end of period 1 , he receives a small private benefit, $b_{1}>0$. At the end of period 2, a completed good project generates a private benefit, $b_{2 g}>b_{1}$, to the entrepreneur. A bad project will not generate any positive outcome in period 2, and it will either be liquidated or reorganized. If it is liquidated, the entrepreneur receives a smaller private benefit, $b_{2 b}$, such that $0 \leq b_{2 b}<b_{1}$. If a bad project is reorganized, it will be completed at the end of period 3 without requiring any entrepreneurial effort. A reorganized bad project generates a private benefit of $b_{3} \in\left(b_{1}, b_{2 g}\right)$.

Presumably, two strategies for reorganizing a bad project during the third period are available, but only one of them generates profit ex-post. The decision depends on signals $s_{A}$ and $s_{B}$, where $s_{J} \in[\underline{s}, \bar{s}], \underline{s}<\bar{s}$ and $J=A, B$. We suppose that signal $S_{J}$ can be observed by the financier only after $I_{3}$ is invested.

In the simple case, $A$ wishes to find a co-financier, $B$, as a commitment device to co-finance a project (or similarly, $B$ looks for $A$, who has a different specialization from that of $B$ ). The following are the conditions under which joint financing by $A$ and $B$ can serve a commitment purpose. The conditions concern how reorganization strategies are related to information $s_{A}$ and $s_{B}$. First, $A$ is specialized in technology $A$, and $B$ is specialized in technology $B$, such that $A$ can only observe $s_{A}$ and $B$ can only observe $s_{B}$. Second, the relationship between $A$ and $B$ satisfies the following efficiency condition (A-1.1): strategy $b$ makes the project ex-post profitable if the value of signal $s_{A}$ exceeds that of $s_{B}$; and strategy $a$ makes the project ex-post profitable if the value of signal $s_{A}$ is less than that of $s_{B}$. Formally,

\footnotetext{
${ }^{4}$ The private benefit received by an entrepreneur at different project dates includes present and future material and nonmaterial gains, such as perks and reputation.
} 


$$
\left\{\begin{array}{ll}
V_{A}^{b}\left(s_{A}, s_{B}\right)+V_{B}^{b}\left(s_{A}, s_{B}\right)>I_{3}>V_{A}^{a}\left(s_{A}, s_{B}\right)+V_{B}^{a}\left(s_{A}, s_{B}\right), & \text { if } s_{A}>s_{B} ; \\
V_{A}^{b}\left(s_{A}, s_{B}\right)+V_{B}^{b}\left(s_{A}, s_{B}\right)=V_{A}^{a}\left(s_{A}, s_{B}\right)+V_{B}^{a}\left(s_{A}, s_{B}\right)=I_{3}, & \text { if } s_{A}=s_{B} ; \\
V_{A}^{a}\left(s_{A}, s_{B}\right)+V_{B}^{a}\left(s_{A}, s_{B}\right)>I_{3}>V_{A}^{b}\left(s_{A}, s_{B}\right)+V_{B}^{b}\left(s_{A}, s_{B}\right), & \text { if } s_{A}<s_{B} ;
\end{array} ;\right.
$$

where $V_{J}^{j}\left(s_{A}, s_{B}\right)$ is the payoff of the reorganized project to be received by the large firm $J$ when strategy $j$ is pursued, and $j=a$, or $b$, and $J=A$, or $B$.

Moreover, the relationship between $A$ and $B$ satisfies the second efficiency condition (A-1.2): the outcome of a poor strategy is so bad that the expected net payoff of randomizing between the two strategies is worse than liquidation, i.e.,

$q V^{b}\left(s_{A}, s_{B}\right)+(1-q) V^{a}\left(s_{A}, s_{B}\right)-I_{3}<0$,

where $V^{a}\left(s_{A}, s_{B}\right)=V_{A}^{a}\left(s_{A}, s_{B}\right)+V_{B}^{a}\left(s_{A}, s_{B}\right), \quad V^{b}\left(s_{A}, s_{B}\right)=V_{A}^{b}\left(s_{A}, s_{B}\right)+V_{B}^{b}\left(s_{A}, s_{B}\right)$ and $q=\operatorname{Pr}\left(s_{A}>s_{B}\right)$.

Finally, the two co-financiers, $A$ and $B$, have a conflict of interest (condition A-2) in choosing reorganization strategies. For the case in which the value of $s_{A}$ is higher, it is more beneficial to financier $A$ if the project is reorganized under strategy $a$ than under strategy $b$ and vice versa, which implies that each financier $J$ has an incentive to adopt strategy $J$ if their own signal value rises. Formally, for any $s^{h}>s^{l}$,

$V_{A}^{a}\left(s_{A}^{h}, s_{B}\right)-V_{A}^{a}\left(s_{A}^{l}, s_{B}\right)>V_{A}^{b}\left(s_{A}^{h}, s_{B}\right)-V_{A}^{b}\left(s_{A}^{l}, s_{B}\right)>0$,

$V_{B}^{b}\left(s_{A}, s_{B}^{h}\right)-V_{B}^{b}\left(s_{A}, s_{B}^{l}\right)>V_{B}^{a}\left(s_{A}, s_{B}^{h}\right)-V_{B}^{a}\left(s_{A}, s_{B}^{l}\right)>0$.

Hereinafter, we provide one example illustrating that the above assumptions apply to real-life circumstances.

Example: Suppose that a project aims to develop a revolutionary gene-therapy-based drug for a broad range of heart diseases. Financier $A$ specializes in traditional drugs for heart diseases (e.g., a large pharmaceutical company) and has access to information on marketing/retailing that type of drug, $\tilde{s}_{A}$. Financier $B$ specializes in evaluating gene-therapy technologies (e.g., a venture capitalist specialized in the field) and has access to information on the cost of gene-therapy products, $\tilde{s}_{B}$. Thus, if A finances the project alone (e.g., a large firm purchases the $R \& D$ project), A will collect $\tilde{s}_{A}$ without cost and $\tilde{s}_{B}$ with extra costs (e.g., the 
cost of hiring experts). If $A$ and $B$ jointly finance the project, they will gather relevant information based on their expertise without extra cost. If the project is a good one, it will be completed on date 2 regardless of whether it is financed by $A$ alone or by $A$ and $B$ jointly. For the case in which the project is a bad one, the existing reorganization strategies are the following: strategy a-replacing the pure gene-therapy-based approach with a mixed technology (e.g., a technology combining a gene-therapy approach and traditional ones); or strategy $b$-narrowing the application target down to a smaller range of heart diseases while keeping the pure gene-therapy technology. Which reorganization strategy makes the project ex-post efficient depends on the demand for the potential new drug, signal $s_{A}$, and the cost of producing the potential new drug, signal $s_{B}$. Moreover, $s_{A}$ and $s_{B}$ will be learned from knowledge of $\tilde{s}_{A}$ and $\tilde{s}_{B}$. If $s_{A}>s_{B}$ (the revenue generated by demand from some heart disease patients exceeds the cost of producing the drug using related gene-therapy technology), strategy $b$ is then efficient. Otherwise, strategy $a$ is efficient for reducing the cost of the new drug. Here, we suppose that $q=0.7$ and $I_{3}=109$. The other parameter values and corresponding payoffs are shown in Table 2.

\section{[Table 2 about here]}

It is clear that condition (A-1.2) is satisfied for the parameters in Table 2, and given $s_{A}>s_{B}$ in both cases, applying condition (A-1.1), strategy $b$, with payoff $b, V_{B}^{b}$ is ex-post efficient.

In the example, with an externally co-financed project, if the co-financiers want to reorganize a bad project ex-post, they ought to find a scheme for sharing their private information. Describing the situation alternatively, $B$ needs to find a scheme for purchasing $s_{A}$ from $A$, or vice versa. Without loss of generality, $B$ will purchase private information $s_{A}$ from $A$ only when the price that $B$ has to pay, $T\left(s_{A}, s_{B}\right)$, is not too high.

Hereby, we summarize the timing of the game as follows:

- Date 0: All parties know the distribution of the projects, but none of them know which project is good or bad. The large firm(s) offer(s) a take-it-or-leave-it contract to the entrepreneur. If the contract is signed, the large firm(s) will invest 
$I_{1}$ units of money into the project during period 1, and the large firm(s) will start to observe $\overline{s_{A}}$ and $\bar{s}_{B}$.

- Date 1: By working on the project, the entrepreneur becomes aware of the project's type, but the large firm(s) still does not know the type. If the entrepreneur stops the project, he gets a private benefit of $b_{1}>0$; otherwise, if the project continues, $I_{2}$ units of investment are required from the large firm(s).

- Date 2: The type of project becomes public knowledge:

- If the project is a good type, it will be completed on date 2 and will generate a return of $\hat{V}$ to the large firm(s) after the large firm(s) observe(s) $\bar{s}_{A}$ and $\bar{s}_{B}$; and a private benefit of $b_{2 g}>b_{1}$ is generated for the entrepreneur but costs him $e>0$;

- If it is a bad project, a decision regarding whether to liquidate or reorganize has to be made.

* If the project is liquidated, the large firm(s) get(s) zero and the entrepreneur gets $b_{2 b}<b_{1}$; otherwise,

* If the project is reorganized, $I_{3}$ units of investment are required.

- After investing $I_{3}$, signals $s_{A}$ and $s_{B}$ are observed by the large firm(s), and a reorganization strategy is chosen based on the signals.

- Date 3: A bad project is completed and generates a return of $V$ to the large firm(s) and a return of $b_{1}<b_{3}<b_{2 g}$ to the entrepreneur.

Our theory shows that informational asymmetry between co-financiers as a barrier to information transfer can benefit financiers because the information barrier can be helpful in stopping bad R\&D investments promptly. That is, external co-financing hardens budget constraints. Proofs of all the propositions and corollaries are in the appendix, which is available in the online version.

Proposition 1. Under assumptions (A-1) and (A-2) with non-integration, all bad projects are liquidated at date 2.

Corollary 1. Under external co-financing, entrepreneurs are induced to stop bad projects on date 1 but to continue good projects.

However, when a project is financed internally or by only one financier, the financier will have all of the information about $s_{A}$ and $s_{B}$; he or she will apply that 
information to choose an ex-post efficient strategy to reorganize the project such that payoff $V^{*}\left(s_{A}, s_{B}\right)$ is greater than the ex-post cost of refinancing, $I_{3}$. Therefore, when the financier spots the bad type of project on date 2, given that earlier investments are sunk and $V^{*}\left(s_{A}, s_{B}\right)>I_{3}$, the financier will choose to reorganize the bad project.

When the entrepreneur at date 1 discovers that his project is bad, he expects that the project still will be backed by the financier on date 2 and anticipates a private benefit of $b_{3}>b_{1}$. Therefore, the entrepreneur will choose not to reveal the type of project if it is a bad one. Hereinafter, we demonstrate that at equilibrium, the financier will decide not to reward the entrepreneur to reveal the project's type at date 1 . The following Proposition 2 summarizes the results.

Proposition 2. Under assumption (A-1), at equilibrium, a financier does not reward an entrepreneur for revealing the type of project at date 1 and does not liquidate bad projects on date 2. As a result, bad projects always are reorganized by a single financier.

Comparing Proposition 1 with Proposition 2, it is clear that external co-financing enjoys benefits over internal financing. However, extra costs are associated with non-integration as opposed to integration or internal financing. The asymmetric information between a startup firm and its financiers gives rise to both moral hazard and adverse selection problems. As a result, if commitment is not the major problem, non-integration may be costlier than integration. In the following, we present the tradeoff between the benefits and costs associated with non-integration.

Corollary 2. Without a deterrent effect, liquidation alone is less efficient than reorganization. However, with a deterrent effect, the institution that commits to liquidation can be more efficient.

Although liquidation can be less efficient than reorganization, commitment to liquidating bad projects plays a fundamental role in deterring entrepreneurs from hiding private information. Therefore, an institution that commits to liquidating bad projects can be more efficient.

However, the boundary of the firm also is influenced by the uncertainties of R\&D projects. Denoting exogenously given institutional cost of non-integration as $c^{N}$ and the cost of collecting signals in the case of integration as $c^{I}$, and assuming that $c^{N}>c^{I}$, we have the following results.

Proposition 3. If $0<c^{N}-c^{I}<I_{2}+I_{3}-V$, a critical level of uncertainty about the 
project, $\lambda^{*}$, exists such that if uncertainty is low, that is, $\lambda<\lambda^{*}$, integration is more efficient than non-integration; otherwise, non-integration is more efficient.

Proposition 4. If $0<c^{N}-c^{I}<I_{2}+I_{3}-V$, the advantage of non-integration over integration increases as

a. $\lambda$ increases;

b. the institutional cost of non-integration, $c^{N}$, declines;

c. the costs of required investment at the respective second and third periods, $I_{2}$ and $I_{3}$, increase; and

d. the return from a bad project, $V$, declines.

The foregoing results imply that highly uncertain $R \& D$ projects tend to be carried out by independent, externally financed small firms. Most high-tech projects in fields such as computers, software and biotech are characterized by great uncertainties. ${ }^{5}$

On the other hand, less uncertain projects tend to be concentrated in large firms because integration is more efficient. Hence, large enterprises with adequate cash flows devote more attention to perfection-related or cost-reduction-related innovation and less attention to new-product-related innovation. However, in the socialist economy, R\&D always will be financed internally since only one firm (the state) exists.

Our theoretical predictions are consistent with observations that scholars have made about drug discovery. They have argued that fueling $R \& D$ pipelines and terminating failing projects quickly (e.g., fast-fail or quick-kill strategies) are keys for pharmaceutical firms in dealing with high-level uncertainties and sustaining development (Lendrem and Lendrem 2013; McMeekin et al. 2020). Unless failing projects are terminated, they clog the pipeline and add R\&D costs. However, large pharmaceutical firms are unable to terminate failing projects (Peck et al. 2015). The same logic can be applied to explain why, in the 1970s, IBM contracted out its first-generation PC CPU chips to Intel and its operating system to Microsoft. We will test our predictions systematically in the next section.

\section{Empirical investigations}

\subsection{NMEs as a measure of disruptive innovations}

Our theoretical model predicts that syndicated investment serves as a commitment device for terminating bad investment projects, thereby enhancing the productivity of

\footnotetext{
${ }^{5}$ In the very early stages, particularly with regard to basic research, high-tech R\&D projects often are funded by the US government through the National Science Foundation (NSF), the National Aeronautics and Space Administration (NASA) and the National Institutes of Health (NIH). Regardless of the source of financing, selection mechanism, such as the one we study here, is a key factor determining R\&D outcomes.
} 
highly uncertain R\&D projects. To test our theory empirically, we need a good measure of disruptive innovation, which is a piece missing from the existing literature. Patent counts and patent citation counts are deficient for measuring disruptive innovations because the definition of patents is too broad to identify revolutionary discoveries.

We argue that so-called new molecular entities (NMEs) provide an objective measure of disruptive innovation (at least approximately) for several reasons. First, much of the R\&D investment in the pharmaceutical industry is meant to develop NMEs, which is the most significant aspect of innovation in that industry (PhRMA 2018). Second, the FDA, enforces rigorous regulations addressing the novelty, efficacy and safety of NMEs, based entirely on standardized sets of evidence. It is important to note that the race to discover NMEs is freely competitive in which the FDA's ex-post judgments do not play a role. The total number of patents granted for relevant drug research over the same sample period of 1998 to 2018 is 229 times larger than the number of NMEs, which thus far are more likely than patents to lead to revolutionary inventions. ${ }^{6}$

The process for discovering NMEs is extremely uncertain and costly (Lendrem and Lendrem 2013; McMeekin et al. 2020). Each new drug undergoes three phases of clinical trials before it is approved by the FDA for commercial sale. It is not until the end of phase III that a new drug can be approved. Moreover, even if approval is granted, a drug may be recalled during post-approval phase IV. In the absence of final marketing approval, all R\&D investments for a specific NME may be a sunk cost. According to PhRMA, it takes an average of 10 to 15 years for a US pharmaceutical company to develop an NME, and of the total cost of NME development, $64.1 \%$ is to pay for clinical trials. Furthermore, more than $88 \%$ of drugs entering clinical trials eventually fail. For example, the failure rate of clinical trials for Alzheimer's drug candidates between 2002 and 2012 was $99.6 \%$, with a Phase I failure rate of $72 \%$, a Phase II failure rate of $92 \%$, and a Phase III failure rate of $98 \%$ (Cummings et al. 2014). The average cost of developing an NME in the early 2010s was $\$ 2.6$ billion, including the cost of failure (PhRMA 2019).

Between 1950 and 2008, only 6\% of the 4300 companies engaged in drug innovation had at least one NME approved by the FDA (Munos 2009). According to the FDA, between 1998 and 2018, approximately 30 NMEs were approved per year. ${ }^{7}$ Thus, among the thousands of firms investing in drug development, only very few are likely to develop NMEs. The turnover of firms in the pharmaceutical industry has been extremely high in recent decades. Of the 261 firms that obtained NME approvals between 1950 and 2008, only 12\% survived over the entire period, while $88 \%$ either failed, were merged or acquired, or were new entries during the more than five-decade-long period (Munos 2009). Moreover, the turnover of firms has risen in

\footnotetext{
${ }^{6}$ The total number of patents granted to the class "Drug, bioaffecting, and body treating compositions" (i.e., CCL/424 or CCL/514) between 1 Jan 1998 and 31 Dec 2018 was 144,385 (https://www.uspto.gov/). That is, the average annual number of patents granted closely related to drug development during our study period was 6,875 . Some other CCLs, such as CCL/435 (Chemistry: molecular biology and microbiology) or CCL/436 (Chemistry: analytical and immunological testing), are not included because those categories sometimes cover things other than drug development. Hence, we understate the total number of drug development patents in general.

${ }^{7}$ https://www.fda.gov/drugs/new-drugs-fda-cders-new-molecular-entities-and-new-therapeutic-biological-products/new-drug-ther apy-approvals-2019
} 
recent decades. Among NME developers, 38 firms entered and 21 exited in the 1980s; 85 firms entered and 67 exited in the 1990s; and 187 firms entered and 124 exited in the 2000s (Kinch et al. 2014).

An analysis of more than 1,222 NMEs approved between 1950 and 2008 reveals that the share of NMEs developed by the 15 largest firms has dropped substantially since the 1980s (Munos 2009). Additionally, the cost of developing NMEs was substantially lower for small firms than for large firms. By 2008, 4,300 small biotechnology companies were spending $\$ 28$ billion annually on R\&D (Munos 2009), whereas a small number of large pharmaceutical firms were spending $\$ 50$ billion annually on R\&D activities (PhRMA 2009). The total number of NMEs developed by small firms exceeded that of large firms by a wide margin (Munos 2009).

Although inventing or discovering NMEs is necessary for a pharmaceutical company to remain competitive in the market, the ability to devise new drugs is not sufficient by itself for pharmaceutical companies to survive owing to the very high costs involved in drug development, marketing and distribution. Consequently, the formation of strategic R\&D alliances between large pharmaceutical companies that take advantage of economies of scale and independent small firms that excel in dealing with highly uncertain discoveries and inventions has become a trend in recent decades. Applying our theory to disruptive innovation in the pharmaceutical industry, we anticipate that undertaking larger numbers of parallel independent projects will increase the chances of success in discovering NMEs in the face of high uncertainty.

In Table 3, we extend the Kornai table by stratifying NMEs by nation between 1998 and 2018. All approved NMEs were discovered by firms in capitalist economies; none of them were introduced in former or current socialist economies, such as the Soviet Union and China.

\section{[Table 3 about here]}

Consistent with our theory, R\&D in the pharmaceutical industry involves a large number of small, independent biotech firms interacting with large pharmaceutical companies. Since 1980, 4,156 US startup biotech firms (or $90 \%$ of all biotech startups in the United States) have received 9,152 rounds of VC investment, among which 1,210 firms (29\%) are backed by corporate VC funds. ${ }^{8}$ Almost all large pharmaceutical companies are active in establishing corporate $\mathrm{VC}$ units to engage with small, independent biotech startup firms. The 15 largest pharmaceutical firms manage 60 investment arms and 90 limited partnership (LP) VC funds for financing biotech startups. From 1980 to 2009, large pharmaceutical companies entered into 29,968 R\&D agreements with small biotechnology companies or other independent research institutes (Deloitte Recap).

\subsection{Empirical results}

To provide systematic evidence for our theory, we investigate the mechanisms responsible for creating the NMEs that were granted approval by the FDA between

\footnotetext{
${ }^{8}$ All statistics are sorted based on the information from CapitalIQ, a financial database constructed by Standard and Poor's.
} 
1998 and 2018, all of which were developed in capitalist market economies.

Data on NME approvals come from the FDA's website, which discloses the names of applicants, active ingredients, and approval dates for each NME. In total, 271 firms were granted at least one NME approval between 1998 and 2018. Based on the information provided, we build a firm-level panel dataset for the number of NME approvals granted to the 271 firms per year. We construct two independent variables. $N M E$ is the total number of NME approvals granted to a given firm in a given year. $N M E \_D$ is a dummy variable that equals one if the firm is granted at least one NME approval in a given year and zero if otherwise.

To investigate the R\&D outsourcing of pharmaceutical firms in the process of NME development, we collect data on strategic R\&D alliance deals entered into by the 271 firms, each of which has developed at least one NME in the past two decades. The R\&D alliance observations come from the Recap database, which provides information on the parties to R\&D alliance agreements, dates of the agreements, drug targets, and contract terms. Specifically, an R\&D alliance agreement is a contract between the "client companies" that are outsourcing the R\&D project to biotech agent firms. We sort the information by the number of alliance deals per sampled firm, i.e., per client company per year. For instance, if more than one "client company" firm is involved in one strategic R\&D alliance deal, we count one deal for each client company. To capture the lagged effects of strategic alliances and avoid bias by any outlier in a specific year, we enter the total number of strategic alliance deals consummated from 5 to 10 years before a sampled firm obtained FDA approval of an NME (denoted by Alliance_10) in a given year (it takes 10 to 15 years to develop a new drug). For instance, for a firm receiving FDA approval for NMEs in 2018, we count the number of outsourcing deals headed by that firm between 2008 and 2012 . For robustness, we also extend the lag to between 5 and 15 years before obtaining FDA approval of the NME (denoted by Alliance_15). For instance, for NMEs developed by a firm that were approved in 2018, we count the number of outsourcing deals headed by that firm between 2003 and 2012 .

In addition to $R \& D$ alliances, some firm-specific factors, such as size, financial performance, and R\&D inputs likewise may affect firms' capacities for developing new drugs. However, only publicly traded firms disclose the aforementioned information. In our regression analysis, we enter a dummy variable (denoted by List) that equals one if a firm is listed in a given year, and zero otherwise, to identify whether a firm is publicly traded. A total of 119 of the 271 companies in our sample are publicly traded. We obtain financial information for the listed firms from Wharton Research Data Services (WRDS). We measure firm size by its total assets in a given year in natural logarithms (denoted by Size); financial performance by a firm's return on total assets (denoted by $R O A$ ) in a given year; and R\&D intensity by the ratio of a firm's R\&D expenditures to total sales in a given year (denoted by $R \& D$ ).

Table 4 presents summary statistics for the variables. From 1998 to 2018, on average, each firm had 0.11 NMEs approved per year, establishing approximately eight R\&D outsourcing deals over a five-year period and 15 such deals over a 10 -year period. The average total assets of listed firms was $\$ 30.46$ billion, and most 
companies allocated $13.24 \%$ of their total sale revenues to R\&D. Moreover, the uncertainty of that kind of R\&D was exceptionally high: the average ROA for the listed pharmaceutical firms during that period was $-21 \%$, whereas the maximum ROA was $175 \%$, implying that the majority of firms were sustaining losses while only a few successful ones were generating positive returns.

[Table 4 about here]

All of the pharmaceutical firms were active in forming R\&D alliances. The 271 firms outsourced 9,544 R\&D projects, averaging more than 35 deals per firm, between 1984 and 2009 (1.4 per year). The largest NME-developing companies, such as GlaxoSmithKline, Merck, Schering, and Roche, outsourced much more than the others; each of them outsourced more than $400 \mathrm{R} \& \mathrm{D}$ projects during the examination period. The distribution of the NMEs is skewed: 182 (67\%) of the 271 firms saw only one NME approved during the 21-year period, and only Pfizer, Johnson \& Johnson, Merck, and Novartis obtained more than one NME per year during the period.

Table 5 illustrates the summary statistics of the number of strategic R\&D alliances formed and NMEs obtained by our sample firms in each year. Panels A and B report the cases of Alliance_10 and Alliance_15, respectively. Firms that formed more R\&D alliances obtained more NMEs. Taking the year 2018 as an example, we observe that the firms obtaining no NME approvals in that year, on average, had formed 5.11 R\&D alliances in the past (the case of Alliance_10). In contrast, firms that obtained one or more NME approvals the same year, on average, had formed 17.41 R\&D alliances. The summary data also seem to indicate a trend, particularly up to 2016, of pharmaceutical firms increasingly adopting R\&D alliance strategies, which may raise their chances of obtaining NME approvals.

[Table 5 about here]

Disruptive innovation is highly uncertain: its success is related to the number of parallel studies pursued. Our theory predicts that institutions with a commitment to terminating bad projects ex-post are more efficient in undertaking larger numbers of parallel R\&D projects. In the context of NME development, we assume that firms entering more R\&D alliances are more likely to develop NMEs. To test our theory, we run regressions on the relationship between NME development and the number of R\&D alliances.

Table 6 reports the regression results (in the case of Alliance_10). In Models 1 and 2, we rely on the full sample that includes both listed and unlisted firms. Owing to the unavailability of financial information for unlisted firms, we control for only a handful of available variables, such as whether the firm is listed or not (denoted by List), and year and firm fixed effects. Model 1 presents the negative binomial regression results, in which the dependent variable is the number of approved NMEs a firm obtained in a given year. Model 2 presents the logit regression results, in which the dependent variable is whether a firm was granted at least one NME in a given year. 
Both models show that the number of R\&D alliances established by pharmaceutical firms is positively and significantly related to NME development. Notably, increasing the number of $R \& D$ alliances by 10 leads to a $1.9 \%$ increase in the probability of a firm obtaining approval for an NME, or roughly 0.16 additional NMEs for the firm.

[Table 6 about here]

Models 3 and 4 of Table 6 report the regression results for listed firms. In addition to the year, stock exchange, and firm-level fixed effects, we control for firm size, financial performance, and R\&D investment in the two regression models. The results show that the number of $R \& D$ alliances established by pharmaceutical firms again is positively and significantly correlated with the probability of obtaining an NME approval and the number of such approvals granted. If the number of R\&D alliances increases by 10, the probability of obtaining the approval of an NME rises by $1.6 \%$, which translates into 0.06 more NMEs. Meanwhile, firm size is positively and significantly associated with NME development. A plausible interpretation is that larger firms form more R\&D alliances than smaller firms do, giving raising their likelihood of developing NMEs and subsequent expansion.

For robustness checks, we estimate regressions with the number of $R \& D$ alliances established between 5 and 15 years before the approval of a firm's NME.

[Table 7 about here]

The results shown in Table 7 are fully consistent with our findings in Table 6 .

\section{Conclusion}

The present paper revisits Kornai's (2013) comparison of capitalism's dynamism versus the failures of socialist economies in fostering revolutionary changes.

We study how the ownership structures of R\&D projects in capitalist economies are purposefully arranged differently in sectors where innovation is more likely to be revolutionary and subject to greater uncertainty than in other sectors. We find that the ownership structure of R\&D projects affects firms' capacities for committing to terminating failing projects. The logic of our theory explains why disruptive innovation cannot be fostered in a socialist economy: socialist economies are based on state ownership and cannot imitate the hard budget constraint mechanism of capitalist economies. Our empirical findings based on a novel measure of disruptive innovations in the pharmaceutical industry support the theoretical predictions.

Our findings offer a corresponding interpretation of the failures of centralized economies in disruptive innovation. With the entire economy controlled by one owner, i.e., the state, $R \& D$ projects are financed "internally" by the same owner at all times. In the pharmaceutical/biotech and other high-tech industries, such as computers and electronics, where R\&D projects are characterized by high levels of uncertainty, non-integrated organizations are more efficient than integrated ones in creating 
innovations. The high levels of integration of centralized economies imply serious inefficiencies for $\mathrm{R} \& \mathrm{D}$ projects owing to the absence of an ex-post screening mechanism. Our theory helps explain why socialist economies, including the former Soviet Union and China, have failed to catch up with the West in areas such as new drugs, semiconductor chips, and computer system software despite their enormous efforts. 


\section{Acknowledgments}

We thank Prof. Eric Maskin for his generous help on an early version of the present paper; Prof. William Shughart II and two anonymous referees for helpful comments and suggestions; and Mr. Zhongming Shi and Ms. Cindy Tian for their skilled research assistance. Chenggang $\mathrm{Xu}$ acknowledges support from the CKGSB and the hospitality of Corvinus University of Budapest, Imperial College London, and LSE.

The views and errors are those of the authors, and they do not necessarily reflect those of their affiliated institutions. 


\section{References}

Acemoglu, D., Aghion, P., \& Zilibotti, F. (2006). Distance to frontier, selection, and economic growth. Journal of the European Economic Association, 4(1), 37-74.

Acemoglu, D., Akcigit, U., Alp, H., Bloom, N., \& Kerr, W. (2018). Innovation, reallocation, and growth. American Economic Review, 108(11), 3450-91.

Adams, W., Einav, L., \& Levin, J. (2009). Liquidity constraints and imperfect information in subprime lending. American Economic Review, 99(1), 49-84.

Aghion, P., Bloom, N., Blundell, R., Griffith, R., \& Howitt, P. (2005). Competition and innovation: An inverted-U relationship. The Quarterly Journal of Economics, 120(2), 701-728.

Coase, R. H. (1937). The nature of the firm. Economica, 4(16), 386-405.

Coase, R. H. (1992). 1991 Nobel lecture: The institutional structure of production. American Economic Review, 82(4), 713-719.

Cummings, J. L., Morstorf, T., \& Zhong, K. (2014). Alzheimer's disease drug-development pipeline: few candidates, frequent failures. Alzheimer's Research \& Therapy, 6(4), 1-7.

Dewatripont, M., \& Maskin, E. (1995). Credit and efficiency in centralized and decentralized economies. The Review of Economic Studies, 62(4), 541-555.

Esty, B. C., \& Megginson, W. L. (2001). Syndicate structure as a response to political risk in the project finance loan market. Working Paper. Harvard Business School, Boston.

Grossman, S. J., \& Hart, O. D. (1986). The costs and benefits of ownership: A theory of vertical and lateral integration. Journal of Political Economy, 94(4), 691-719.

Hall, B. H., \& Lerner, J. (2010). The financing of R\&D and innovation. In Handbook of the Economics of Innovation (Vol. 1, pp. 609-639). North-Holland.

Hart, O. D. (1995). Firms, contracts, and financial structure, Oxford University Press.

Hart, O. D. (2017). Incomplete contracts and control. American Economic Review, 107(7), 1731-52.

Hart, O. D., \& Moore, J. (1990). Property rights and the nature of the firm. Journal of Political Economy, 98(6), 1119-1158.

Huang, H., \& Xu, C. (1998). Soft budget constraint and the optimal choices of research and development projects financing. Journal of Comparative Economics, 26(1), 62-79.

Huang, H., and Xu, C. (1999). Institutions, Innovations, and Growth. American 
Economic Review, 89 (2): 438-443.

Kealey, T. (1996). The economic laws of scientific research. London: Macmillan.

Kinch, M. S., Haynesworth, A., Kinch, S. L., \& Hoyer, D. (2014). An overview of FDA-approved new molecular entities: 1827-2013. Drug Discovery Today, 19(8), 1033-1039.

Klein, D. B., \& Tabarrok, A. (2002), Is the FDA safe and effective. An extensive website sponsored by the Independent Institute (FDAreview. org).

Koppl, R. (2018), Expert failure, Cambridge University Press.

Kornai, J. (1979). Resource-constrained versus demand-constrained systems. Econometrica: Journal of the Econometric Society, 47(4), 801-819.

Kornai, J. (1986). The soft budget constraint. Kyklos, 39(1), 3-30.

Kornai, J. (2013). Dynamism, rivalry, and the surplus economy: Two essays on the nature of capitalism. Oxford University Press.

Kornai, J., Maskin, E., \& Roland, G. (2003). Understanding the soft budget constraint. Journal of Economic Literature, 41(4), 1095-1136.

Lasser, K. E., Allen, P. D., Woolhandler, S. J., Himmelstein, D. U., Wolfe, S. M., \& Bor, D. H. (2002). Timing of new black box warnings and withdrawals for prescription medications. Journal of the American Medical Association, 287(17), 2215-2220.

Lendrem, D. W., \& Lendrem, B. C. (2013). Torching the haystack: modeling fast-fail strategies in drug development. Drug Discovery Today, 18(7-8), 331-336.

Lenin, Vladimir (1917[1993]). State and revolution. London: Penguin Books.

Maskin, E. (1992). Auction and privatization. in Siebert, H., eds. Privatization, pp. 115-136.

McMeekin, P., Lendrem, D. W., Lendrem, B. C., Pratt, A. G., Peck, R., Isaacs, J. D., \& Jones, D. (2020). Schrödinger's pipeline and the outsourcing of pharmaceutical innovation. Drug Discovery Today, 25 (3), 480-484.

Munos, B. (2009). Lessons from 60 years of pharmaceutical innovation. Nature Reviews Drug Discovery, 8(12), 959-968.

Peck, R. W., Lendrem, D. W., Grant, I., Lendrem, B. C., \& Isaacs, J. D. (2015). Why is it hard to terminate failing projects in pharmaceutical R\&D? Nature Reviews Drug Discovery, 14(10), 663-664.

Qian, Y., \& Xu, C. (1998). Innovation and bureaucracy under soft and hard budget constraints. The Review of Economic Studies, 65(1), 151-164. 
Ridley, M. (2020). How innovation works: And why it flourishes in freedom, New York: Harper.

Scherer, F. M. (1991). Changing perspectives on the firm size problem. Innovation and Technological Change: An International Comparison, 24-38.

Scherer, F. M. (1992). Schumpeter and plausible capitalism. Journal of Economic Literature, 30(3), 1416-1433.

Schumpeter, J. (1950) Capitalism, socialism and democracy, New York: Harper.

Steijvers, T., \& Voordeckers, W. (2009). Collateral and credit rationing: A review of recent empirical studies as a guide for future research. Journal of Economic Surveys, 23(5), 924-946.

Williamson, O. (1975), Markets and hierarchies, New York: The Free Press. 
Table 1 Characteristics of innovation processes in capitalist and socialist economies

\begin{tabular}{lll}
\hline & Capitalism & Socialism \\
\hline A. R\&D initiatives and decisions & Entrepreneurs/Firms & Government \\
B. Financial rewards to successful entrepreneurs & Enormous & Insignificant \\
C. Competition & Tough & Very weak \\
D. Parallel experiments & Extensive & Very limited \\
E. Project financing & Flexible & Rigid \\
\hline
\end{tabular}

Table 2 Parameter values and their corresponding payoffs

\begin{tabular}{|l|l|l|l|l|l|l|}
\hline & signal $s_{A}$ & signal $s_{B}$ & payoff $V_{A}^{a}$ & payoff $V_{A}^{b}$ & payoff $V_{B}^{a}$ & payoff $V_{B}^{b}$ \\
\hline$s_{A}^{l}$ case & 0.6 & 0.4 & 40 & 45 & 40 & 65 \\
\hline$s_{A}^{h}$ case & 0.7 & 0.4 & 48 & 47 & 40 & 65 \\
\hline
\end{tabular}

Table 3 Number of NMEs introduced, by nation, 1998-2018 ${ }^{9}$

\begin{tabular}{lll}
\hline Country & NMEs (1998-2018) & Share \\
\hline USA & 360 & $56.34 \%$ \\
Switzerland & 55 & $8.61 \%$ \\
UK & 50 & $7.82 \%$ \\
Japan & 39 & $6.10 \%$ \\
Germany & 38 & $5.95 \%$ \\
Ireland & 26 & $4.07 \%$ \\
France & 21 & $3.29 \%$ \\
Canada & 8 & $1.25 \%$ \\
Denmark & 8 & $1.25 \%$ \\
Netherlands & 7 & $1.10 \%$ \\
\hline
\end{tabular}

\footnotetext{
${ }^{9}$ We determine the home countries of pharmaceutical firms by the locations of their headquarters. Between 1998 and 2018,612 NMEs were invented, a small number of which were discovered by more than one firm working together. If we count each firm as one point of calculation, the total number of involved firms is 639 .
} 
Table 4 Summary statistics

\begin{tabular}{lrllll}
\hline Variable & Obs & Mean & Std. Dev. & Min & Max \\
\hline NME & 5,689 & 0.112 & 0.389 & 0 & 4 \\
Alliance_10 & 5,542 & 7.989 & 20.172 & 0 & 215 \\
Alliance_15 & 4,978 & 14.709 & 36.208 & 0 & 386 \\
ROA & 1,339 & -0.210 & 0.677 & -12.028 & 1.750 \\
R\&D (\%) & 1,198 & 13.244 & 64.360 & 0.015 & 533.535 \\
Size (total asset) (\$mil) & 1,345 & 30459.86 & 156023.5 & 0 & 1736344 \\
List & 5,689 & 0.436 & 0.495876 & 0 & 1 \\
\hline
\end{tabular}

Table 5 Number of R\&D alliances and number of NME approvals granted

\begin{tabular}{|c|c|c|c|c|c|c|}
\hline \multicolumn{4}{|c|}{ Panel A: Cases based on Alliance_10 } & \multicolumn{3}{|c|}{ Panel B: Cases based on Alliance_15 } \\
\hline Year & $\mathrm{NME}=0$ & $\mathrm{NME}>=1$ & Diff & $\mathrm{NME}=0$ & $\mathrm{NME}>=1$ & Diff \\
\hline 1998 & 1.45 & 7.35 & $5.9 * * *$ & & & \\
\hline 1999 & 1.42 & 11 & $9.58 * * *$ & & & \\
\hline 2000 & 2.27 & 8.96 & $6.68 * * *$ & 3.02 & 13.45 & $10.43 * * *$ \\
\hline 2001 & 2.74 & 15.28 & $12.54 * * *$ & 3.81 & 20.39 & $16.58 * * *$ \\
\hline 2002 & 3.82 & 10.8 & $6.98 * *$ & 5.41 & 15.07 & $9.66 * *$ \\
\hline 2003 & 4.08 & 23.29 & $19.22 * * *$ & 5.69 & 31.63 & $25.94 * * *$ \\
\hline 2004 & 5.31 & 13.19 & $7.88 * * *$ & 7.39 & 18.06 & $10.67 * * *$ \\
\hline 2005 & 6.11 & 21.83 & $15.73 * * *$ & 8.57 & 29.72 & $21.15^{* * *}$ \\
\hline 2006 & 5.75 & 24.05 & $18.30 * * *$ & 8.74 & 34.95 & $26.21 * * *$ \\
\hline 2007 & 6.7 & 28.3 & $21.60 * * *$ & 10.12 & 41.75 & $31.63 * * *$ \\
\hline 2008 & 7.81 & 24.27 & $16.46^{* * * *}$ & 12.28 & 38.36 & $26.08 * * *$ \\
\hline 2009 & 8.57 & 24.41 & $15.83 * * *$ & 14.3 & 38.1 & $23.80 * * *$ \\
\hline 2010 & 9.54 & 21.43 & $11.89 * *$ & 16.14 & 35.4 & $19.26 * *$ \\
\hline 2011 & 7.75 & 45.21 & $37.47 * * *$ & 12.95 & 66.86 & $53.91 * * *$ \\
\hline 2012 & 9.21 & 28.64 & $19.43 * *$ & 15.92 & 48.31 & $32.39 * * *$ \\
\hline 2013 & 9.88 & 38.95 & $29.07 * * *$ & 17.51 & 65.95 & $48.44 * * *$ \\
\hline 2014 & 7.45 & 48.34 & $40.89 * * *$ & 14.56 & 80.89 & $66.33 * * *$ \\
\hline 2015 & 6.57 & 50.71 & $44.14^{* * *}$ & 13.63 & 86.6 & $21.97 * * *$ \\
\hline 2016 & 8.92 & 57.58 & $48.66^{* * *}$ & 18.15 & 99.83 & $81.68 * * *$ \\
\hline 2017 & 6.18 & 33.79 & $27.61 * * *$ & 14.28 & 66.14 & $51.86^{* * *}$ \\
\hline 2018 & 5.11 & 17.41 & $12.30 * * *$ & 13.31 & 43.73 & $30.42 * * *$ \\
\hline Full sample & 6.03 & 26.81 & $20.78 * * *$ & 11.31 & 48.14 & $36.83 * * *$ \\
\hline
\end{tabular}


Table 6 Estimates of R\&D outsourcing and NME development (outsourcing activities between 5 and 10 years prior to NME approval)

\begin{tabular}{|c|c|c|c|c|}
\hline & (1) & (2) & (3) & (4) \\
\hline & NME & NME_D & NME & NME_D \\
\hline \multirow[t]{2}{*}{ Alliance_10 } & $0.0155 * * *$ & $0.0256^{* * *}$ & $0.00603 * *$ & $0.0154 * * *$ \\
\hline & $(9.98)$ & (11.01) & $(2.63)$ & $(3.84)$ \\
\hline \multirow[t]{2}{*}{ Size } & & & $0.339 * * *$ & $0.341 * * *$ \\
\hline & & & $(5.05)$ & $(4.36)$ \\
\hline \multirow[t]{2}{*}{ ROA } & & & -0.246 & -0.254 \\
\hline & & & $(-1.47)$ & $(-1.27)$ \\
\hline \multirow[t]{2}{*}{ R\&D } & & & 0.000267 & 0.000775 \\
\hline & & & $(0.16)$ & $(0.43)$ \\
\hline \multirow[t]{2}{*}{ List } & $0.352 * *$ & $0.277 *$ & & \\
\hline & $(3.10)$ & $(2.29)$ & & \\
\hline \multirow[t]{2}{*}{ Constant } & 0.217 & $-2.637 * * *$ & -1.935 & $-4.904 * * *$ \\
\hline & $(0.51)$ & $(-11.33)$ & $(-1.20)$ & $(-3.83)$ \\
\hline Year-fixed & Yes & Yes & Yes & Yes \\
\hline Firm-fixed & Yes & Yes & Yes & Yes \\
\hline Exchange-fixed & & & Yes & Yes \\
\hline $\mathrm{N}$ & 5542 & 5542 & 1197 & 1176 \\
\hline
\end{tabular}


Table 7 Estimates of R\&D outsourcing and NME development (outsourcing activities between 5 and 15 years prior to NME approval)

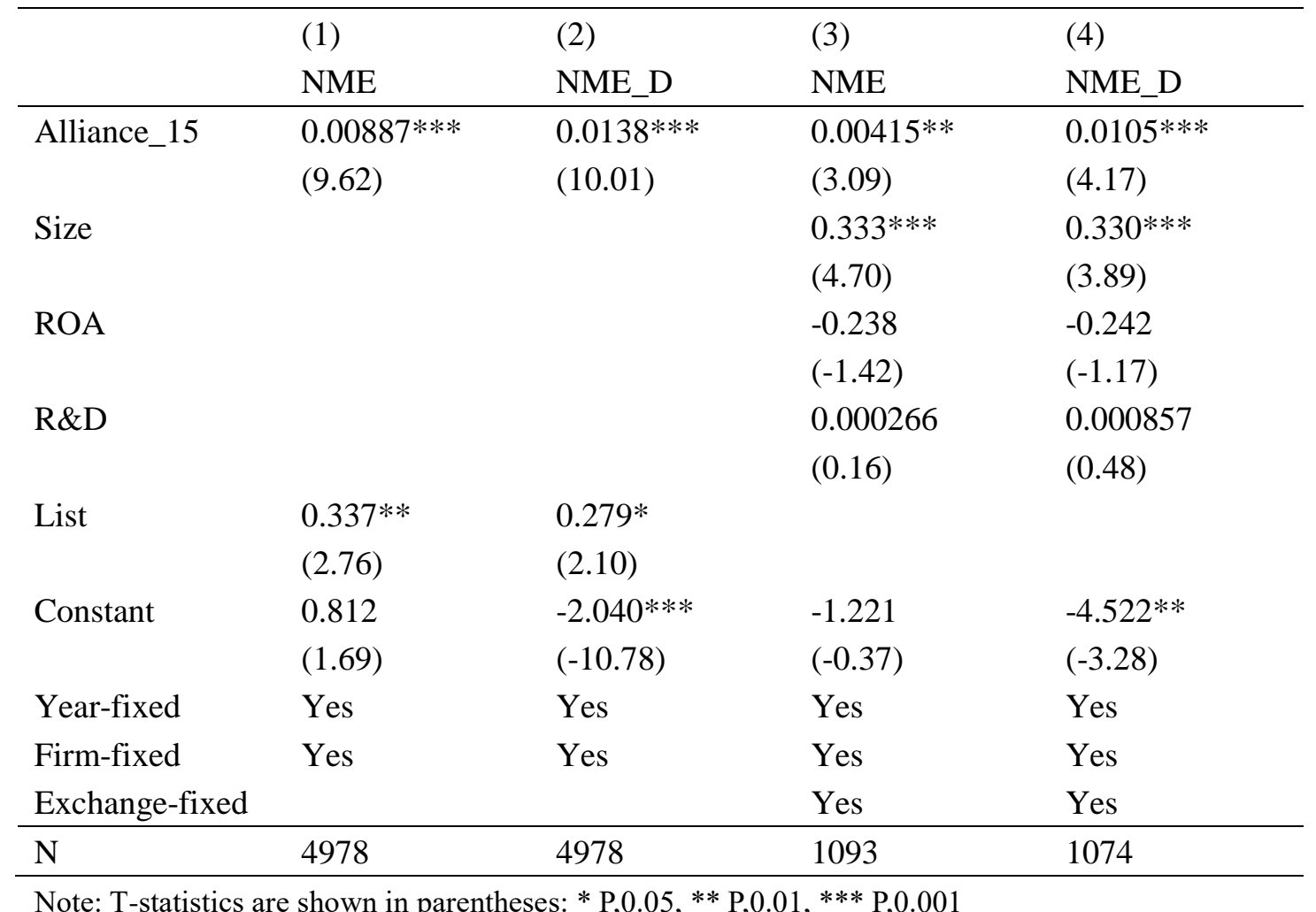

